\section{GROUPING OF THE STRAINS OF MENINGOCOCCUS}

ISOLATED DCRING THE EPIDEMIC OF CERERROSPINAT, MENINGTTIS IN 191:\%

$\mathrm{B}$ Y JOSEPH A. ARKWRIGHT, M.D.,

Troar THe LISTER INSTITCTE OF PRETENTIVE MEDICINE.

THE following account refers oniy to strains of meningo. coccus which were isolated from the cerebro-spinal fluid or meninges of cases of meningitis. All the strains con. formed to the usual morphological and staining characters of the meningococcus. Culturally they did not make growth at the temperature of the laboratory and they fermented glucose but not cane sugar.

The formation of a uniform permanent emulsion in physiological salt solution was a constant characteristic of all the strains, except three, which sometimes showed agolutination in salt solution ( $\mathrm{NaCl} 0.85$ per cent.).

Several of the cultures gave a distinctly yoke-yellow growth on glucose agar; this was especially noticeable in the case of two strains, M. 13 and 4410, on some occasions. Many strains made a very mucilaginous growth on moist glucose agar. 'The culture medium found most convenient for applying the sugar tests was Hiss's serum water. After mixing serum one part with distilled water three parts, the mixture can be autoclared at about $118^{\circ}$ for twenty minutes without causing precipitation of the protein ; 1 per cent. carbohydrate and litmis can then be arded and the tubes steamed three times. Stock cultures were kept on 1 per cent. glucose agar at $37^{\circ}$ in closed tin boxes.

Thirty-five strains were examined, which came from the following sources:

Nine from cases occurring in the first Canadian contingent on Salisbury Plain, found February, 1915

Four other cases occurring in the flrst Canadian contingent on Salisbury Plain, found March, 1915.

Eight cases occurring in the Herbert Hospital, Woolwich, received through the kinduess of Mr. K. Goadby.

Nine cases occurring among soldiers, kindly supplied to me by Major Gordon and Captain Hine, R.A.M.C.

Two cases occurring in France, received from Major $S$. Rowland, R.A.M.C:

Two cases occurring at Reading, received from Dr. Donaldson.

One case occurring at Watford.

Agglutination tests have been performed with two main objects: (1) With polyralent rabbit serum, with the object of obtaining a criterion for the diagnosis of the meningo cocci. (2) With serum prepared from rabbits with singlo strains, in order to determine whether these strains of meningococcus, isolated during the epidemic, fell into rroups.

At the samo time agglutination tests wero made with antimeningococcus and antiparameningococeus serums obtained from the Pasteur Institute, through the kindness of Professor Pioux.

Preparation of Serums.

In order to obtain agglutinating serums, rabbits wero inoculated intravenously with unheated emulsion. Suitable serums, with a sufficiently high titre, were not obtained till tho animal had receired seven to ten injections; the maximum dose given was two glucose agar slopes. For the tests detailed below three rabbit serums wero rescd:

A. prepared from a single strain - Plank.

. prepared from a single strain-M. 13 .

C. prepared from six strains -Carter, Crisp, Plank, Falmer, M. 1, M. 13.

\section{Agglutination Technique.}

Cultures of one day's growth on glucose agar were omulsified in distilled water containing 0.5 per cent. phenol. The serum was diluted with salt solution (0.85 per cent. NaCl). The density of emulsion used was judged by eye, and was of about the consistence obtained by adding $10 \mathrm{c.cm}$. of water to one glucose agar slope. Sorcral strains were tested on the same day, and two or four serums were used on each occasion; the results, therefore, to some extent controlled each other, 4 control tube with salt solution was always included for each strain. and each strain was tested with normal horso or rabbit serum.

Agglutination was not obtained with normal serum with any strain unless agglutination also occurred in salt solution. It was found that rather higher specific agglutination was obtained when the tubes contained salt solution of half or one quarter the usual strength, than when both the emulsion and the serum dilutions were made up witk physiological salt solution ( $\mathrm{NaCl} 0.85$ per cent.).

The agolutination tests were carried out mäcroscopically in small tubes which were put in the incubetor at $37^{\circ} \mathrm{C}$. for eighteen to twenty hours, and then liept on the bench at the temperature of the laboratory. Whien complete agglutination (C) occurred there was completo clearing of the supernatant fluid and marked deposit.

The least degree of agglutination (L) noted was shown by the absence of the small round collection of sedimented cocci, rather larger than a pin's head, seen in the control tubes, and by an irregular granular deposit scattercd over the concave bottom of the tube.

The results obtained with tho multivalent serum C. are shown in Table I. Of 32 strains tèsted, 30 showed agglutination complete or almost completo in a dilution of 1 in 100. One strain (Llandrindod) agglutinated completely, 1 in 800; another strain (Carter) reached ' 1 in 400, and ten strains were completely agglutinated-by a dilution of 1 in 200 . Of the remaining two strains, ope (Kennedy) only gave incomplete agglutination (I) in 1 in 100, and tho other (McPhail) agglutinated slightly in salt solution, and only incompletely in 1 in 100 . Tests with serum C. of strain of Diplococcus flavus, which did not agglutinate in the salt solution control, were negative.

The table also shows the agglutination results obtained with the two univalent rabbit serums $A$. and B., and also with antimeningococcus and antiparameningococcus serum from the Pasteur Institute.

By means of the two serums A. and B. it was possibic to placo 27 out of the 35 strains in one or other of two groups :

17 in Group A. were agglutinated best by Serum A. prepared with strain "Plank."

10 in Group B. were best agglutinated by Serum B. prepared with strain "M. 13 ."

By means of the two Pasteur Institute serunis 27 out of the 35 strains could be divided into two groups:

15 into Group M. agglutinated best by antimeningococcuss

12 in Group 1 . agglntinated by antiparameningococcus serum.

Whenever the strains could be grouped definitely by both pairs of serums-that is, A. and $B$. and $M$. and $\dot{P}$. respectively - a strain falling into Group $A$.álso fell into Group M., and those agglutinated by B. serum were also agglutinated by antiparameningococcus sorum, except in the case of two strains.

It seems, therefore, justifiable to speal of two main groups, A.M. and B.P., corresponding to the meningo. coccus and parameningococcus groups af Dopter. Whenever a strain fell into the B.P. group it appeared to do so quite definitely; the A.M. strains varied more in their agglutinability, and were more influenced by the $\mathbf{B}$. P. serums than the B.P. strain wore affected by the A.M. serums.

By means of these four serums it was possible to defi. nitely group 30 strains - 18 in the A. M. group, and 12 in the B.P. group. One strain could not be classified. One strain (Chandler) a.gglutinated not rery strongly, but equally with $A$. and $B$. serums. One strain (McPhail) agglutinated in salt solution. Two strains (Chase aud Berkhampstead) fell in different groups on two occrsions. Chase was agglutinated best by P. serum on June 25th, and by $M$. serum on August 18th. Berkhampstead was agglutinated by $P$. serum on July 20 th, but not on August 30th, on which latter date it reacted better with $\Lambda$. serum than with B. serum. One strain (Littledale) gave no reaction with the Pasteur Institute sertums, but agglutinated completely with serum $C$.

Some inquiries wero made into the sources of tho strains to find out (1) whether the different localities yielded more of one group of meningococcus than the other; (2) whether the clinical symptoms wore ilifferent or more severe in cases infected with ono group than with the other. No decisive answer coruld bo giren to either 
TABLE I.

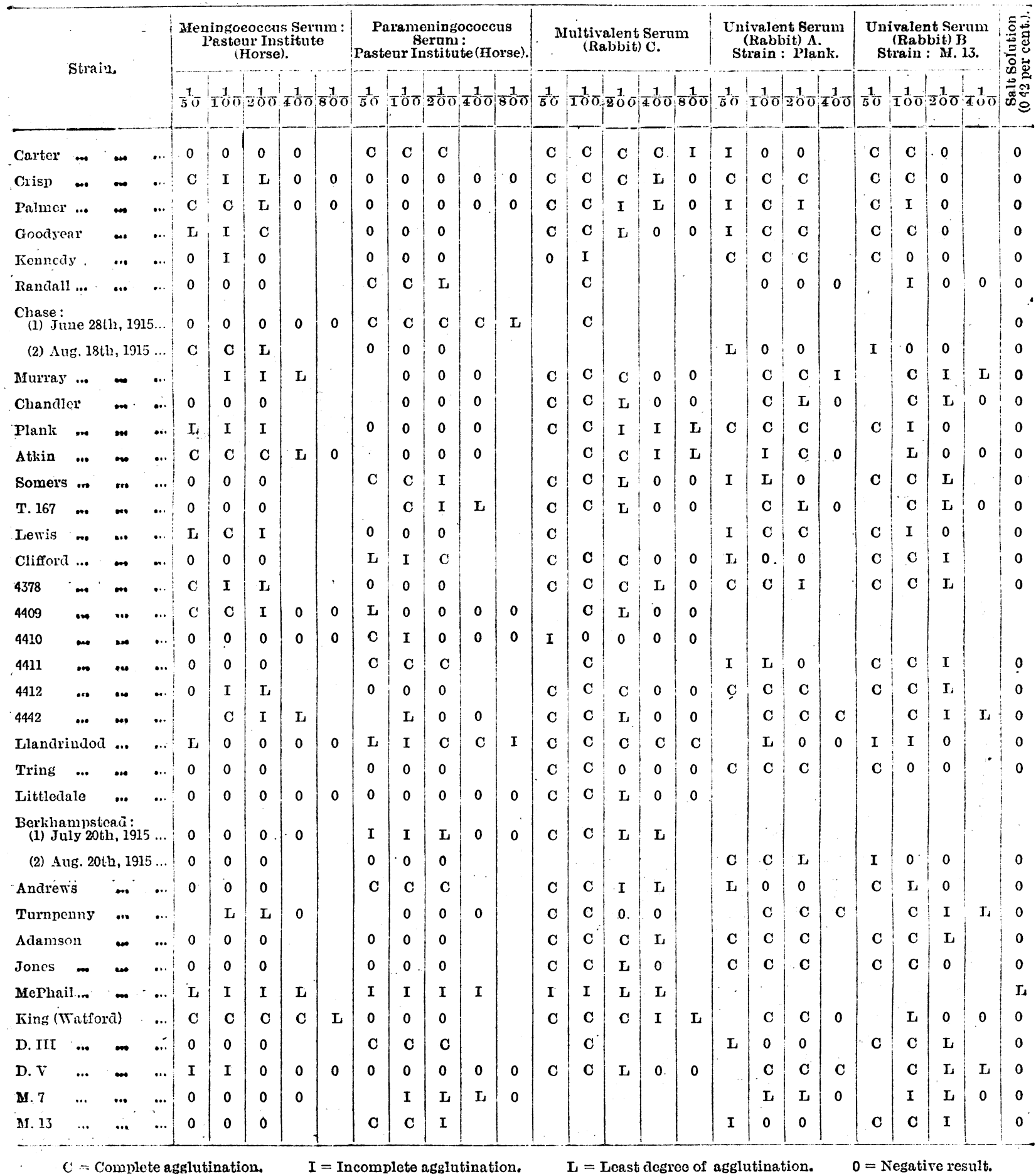

question, and neither inquiry supported the view that these two groups of meningococcus are permanently different stocks causing different types of disease, or were coufined to different epidemiological outbreaks.

'Iable II (p. 887) shows the sources of the strains and their grouping by agglutinating serums.

Who strains from Wooivich and those from Major Gordon and Captain Hine no doubt came from patients of various origin, but the Canadian strains were all isolated in January and February, 1915, and the four other strains from Salisbury Plain also came from cases in the same arca in February and March. Of these thirteeen strains from Salisbury Plain, seven fell in the A. and M. group and four in the B. and $P$. group. D. III and D. V, both coming from Reading in the spring of 1915, fell in different groups.
On analysis of nine cases occurring in the First Canadian Contingent, from which strains of meningococcus were isolated and tested, fire cases were infected with menivgococci of the A. and M. group; of these one recovered, the remainder died within four days of the onset of the disense. Two yielded cultures of the $P$. and $B$. group; one lived five months but eventually died, the other died within two days. The two strains from France--M. 7 and M. 13.-were both B. and P. strain, and both cases wero fatal.

This small series shows that severe and fatal cases of the disease may be associated with either group of the two strains of meningococcus found in this epidenic.

Three strains of meningococcus isolated from the throats of persons in contact with cases of cercbro-spinal meningitis havo been so far examined with tho same 


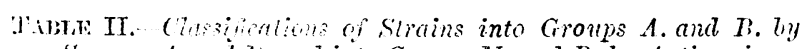
Sorums A, and R, and into Groups M. and P. by ,Antimoningococcus and hutiparaneningecoceus Sorums.

Straine from rases on Salis. bury Ilain. Fingt Candian centingcnl.

Strains.

Crisp..

Tialmos:

Goodyear

Kicnnedy

Chase

Chandicl

Carter:

Randall ...

Sirains from Cases $M T$. $E$. Gocidby (Wooluich)

$\begin{array}{llll}\text { Jewis } & \ldots & \ldots & \text { M. and } A . \\ 4378 & \ldots & \ldots & \text { M. } \\ 4409 & \ldots & \ldots & \text { M. } \\ 4410 & \ldots & \ldots & \text { P. } \\ 4411 & \ldots & \ldots & \text { P. and B. } \\ 4442 & \ldots & \ldots & \text { M. and A. } \\ \text { Clifford } & \ldots & \ldots & \text { P. and B. } \\ 4412 & \ldots & \ldots & \text { M. and A. }\end{array}$

Wrom Ticut. Treadyolet.

Athin $\ldots$... M. and A.

Somers ... $\quad \ldots$ F. Find B.

'Lotal 35: 17 Gronp 1.

15 Group $\mathrm{M}$.

18 Gronp $\Lambda$. and $\mathrm{MI}$.
Murray...

$$
\begin{aligned}
& \text { Civilian. } \\
& \text { Strains. Grouns. } \\
& \text { Plank … } \quad \text {.. M. and } A \text {. } \\
& \text { Strain from Iajor S. Fouland } \\
& \text { (l'rabiel. } \\
& \begin{array}{llll}
\text { M. } 7 & \ldots & \ldots & \text { P. and } P .
\end{array} \\
& \text { Struins from Thojor Gordon } \\
& \text { and Coptain IIinc. } \\
& \text { Tring … } \quad \ldots \quad A
\end{aligned}
$$

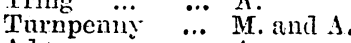

$$
\begin{aligned}
& \text { Adamson } \quad \cdots \quad \Lambda \text {. }
\end{aligned}
$$

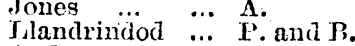

$$
\begin{aligned}
& \Lambda \text { ndrews } \quad \ldots \quad \mathbf{B} \text {. and } \mathbf{B} \text {. } \\
& \text { Berkhampstead } \mathbf{P} \text {. and } \Lambda \text {. } \\
& \begin{array}{lll}
\text { Littledaie } & \ldots . & \text { ? } \\
\text { MePhail... } & \text {... }
\end{array} \\
& \text { Strain from Dr. Donaldson } \\
& \begin{array}{llll} 
& \text { (Teading) } & \\
\text { D. III } & \ldots & \ldots & \text { P. and } \mathrm{B} . \\
\text { D. } & \ldots & \ldots & \text { M. and } A .
\end{array} \\
& \text { Strain from Truford. } \\
& \text { Tatford... ... M. and } A \text {. } \\
& 10 \text { Group B. } \\
& 12 \text { Group } P \text {. }
\end{aligned}
$$

serums. Two of these strains fall definitely into the B. and $P$. group; the third was feebly agglutinated by both M. and $P$. scrums, but more by M. scrum.

\section{Remaris}

In the first twenty years after the discorcry of the meningococcus by Wcichselbaum (1887) the tendency to accentuato the rariability of this organism was carried by Taeger (1895) to the point of claiming for it an ability to change into a Gram-positive diplococcus, which grew readily at $20^{\circ} \mathrm{C}$., and was very resistant to drying. The observations of Councilman, Mallory and Wright (1898), Albrecht and Ghon (1903), and others confirmed the description of Weichselbaum, and ron Lingelsheim (1906) claimed a very high degree of uniformity for the strains isolated by him duning the Silesian epidemic, and stated that all these strains of meningococcus agglutinated with a univalent serum obtaincd by injecting a rabbit with one strain.

Many other writers have reported on the value of agglu. tinating serum for identifying the meningococcus. Several workers, however, especially Eberlo (1908), Flser and Huntoon (1909), Traubmann and Fromme (1908), Arkwright (1909), described undonbted strains of meningococcus which wero inagglutinablo with antimeningococcus serum, and pointed out the irregularity with which univalent scrums affected strains which had not bcen used in thein preparation. Eberle, and Elser and Huntoon, moreover, showed that the serum made with one strain might have a far higher agglutination titre for some strains than they had for others, even if the homologons strain remained relatively inagglutinable. Most of these writers, especially Eberle, and Elser and Huntoon, attributed the irrogu larities observed to the varied agglntinability of different strains and to their different value as antigen (agglutinogon). Houston and Rankin (1907) claimed to be able to differentiate strains of meningococcus obtained from cases of infantile posterior basic moningitis from strains derived from epidemic cases.

In 1909 and 1912 I was able to divide the sporadic and cpidemic strains of meningococeus with which I was working into groups whith did not inter-react, by agglutination and complement fixation tests. The groups appeared to overlap somewhat. By absorption of agglu. tinins the groups conld be further subdivided. My results lod mo to the conclusion that epidemic and sporadic strains were both divisible into an uncertain number of groups which were not closely related serologically, but which werc connected by intermediate strains.
Dopler (1909) descrited a strain which he called para. meningococcus. It was isolated from the naso-pharynx, and rescmbled the meningococcus except in serum re. action. Antimeningococclis serum did not agglutinate the parameningococcus. Subsequently (1911) he recorded the isolation of the parameningococcus from the cerebro-spinal fluid of serere cases of sporadic meningitis, all of which were fatal. He considered that cerebro-spinal meningitis might be caused by eithei the meningococcus or the parameningococcus. Ho also. began preparing therapentic serum from horses for the tiro classes of cases. In 1914 Dopter described three groups of parameningococci differentiated by absorbing agglutinin from antimeningo. coccus and from antiparameningococcus horse serums, and also by univalent rabbit serums. Ho stated that antimeningococcus scrum sometimes agglutinates para. meningococcus strains as well as the meningococcus, but that paramoningococcus scrum usually agglutinates both varieties.

The large majority of the strains examined in the present paper appcar to fall into two main groups which are identical with or closely allicd to the meningococeus and parameningococcus main groups described by Dopter. This has been shown by using Pasteur Instituto therapeutic M. and $P$. serum for agglutination tests. These serums, howerer, are no doubt made by the inoculation of sereral strains, since Dopter (1914) stated that threo parameningococens strains were used for the horsc.

Of the five strains which I hare been tuable to classify, two (Chase and Berkhampstead) appear to occupy an intermodiate position betwecn the two groups, and perhaps contain individual cocci which react with different scrums. One (Littledale) was not agglutinated with tho serums trsed. 'One (Chandler) was fcebly and equally agglutinated by serum for both groups, and therefore perhaps belougs to the $\mathrm{M}$. rather than to the P. group.

The strains belonging to the $B$. and $P$. parameningococcus group appeared to gire sharper differentiating reaction than those of the $A$. and $M$. group. This corresponds with Dopter's observation that parameningococcus serum usually agglutinates meningococci, but that meningococcus serum as a rule has no action on the momber of the other group.

\section{Effect of Therapoutic Sirums.}

The fact that meningococci are not all alike scrologically, but fall into different groups, provides a reason why the therapentic serums used during the 1914-15 cpidemic in this country appeared to have so little valuc. It is probable that the horses from which the serum was derived had not receired the same groups or subgroups as occurred in this epidemic. Howerer, the strains isolated in 1915 appear to fall for tho most part into the same main groups as Dopter's meningococci and paramoningococci which hare been present in France for some ycars.

A. Netter (1915) had very successful results in Franco with the Pasteur Institute serum. His cases showed a mortality of only 22 per cent. without excluding fulminant cases and deaths from other canses.

It has been demonstrated by Filser and Huntoon and other workers that the antigenic properties of different: strains of meningococcus are very different in value. It is therefore very probable that whore large numbers of strains of meningococcus have not been available for immunizing the horses, those strains which offered the best antigen have not been used.

\section{Conclesions.}

1. Thirty out of thirty-two strains of meningococei tested agglutinated with a polyvalent rabbit serum prepared with six strains isolated in the same epidemic.

2. Thirty strains isolated during the present epidemic fall into two main groups according to agglutination tests. Five other strains prosented difficulties in their classification.

3. These two main groups correspond to Dopter's classification into meningococcic and parameningococcic

4. The numbers falling into the two groups-meningococcic and parameningococcic-werc 18 and 12 respectively - that is, 3 to 2 .

5. There is some cridence that tro of the fire un. classified strains werc intermediate in characten between the tro main grotuss. 
6. Neither group was more frequently found among cases from one district than from another.

7. Rapidly fatal cases of meningitis occurred with infection with either type of meningococci.

I must express my thanks to those who have kindly given me cultures, and especially to Captain A. W. M. Ellis, C.A.M.G., who isolated many Canadian strains, and to Major. Gordon and Captain Hine, R.A.M.C. To these and other workers I am indebted for cultures and for help. I look forward with great interest to the publication of the results obtained from their work during the present year.

\section{BIBLIOGRAPITY}

Arkwright, J. A. (1909): Virieties of the Meningococcus, with special reference to a Comparis on from Epidemic and Sporadic Sources. Journ. of Hyg., vol. ix, p. 104.

Arkwright (ig12): The Serum Reactions (Complement Fixation) of

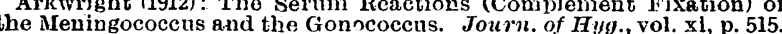
the Meningococcus and the Gonncoccus. Journ. of Hyg., vol. xl, p. 515 voising du méningocoque (paraméningocoque). Compt. rend. Soc. de Biol., 1909, vol. ii, 1). 74

Dopter (1911): Méningite Cérébrospinales à paraméningocoques. Bull de l'Inst. Pasteîr. 1911 , p. 940.

. Dopteret Yauron $(1914)$ : Différenciation des paraméningoconuc entro eux par la saturation des agglutinines. Compt. rend. Soc. te Biol. 1914, voi. ii, p. 231.

f. Herle, J. (1908): Ceber Agglutination der Meningohokken. Archiv Elser, IV. J., and Hin

and Huntoop, F. M. (1909): Studies on Meningitis. Houston. T., and Rankin, J. Yx, (N.S., xy), 1). 373.

and Afglutinative Action of Blood Serum in Cerebro-spinal Fever. Bmisish Medical

JodR Lu, vol. ii, p. 1414. o Schl. während der Geniclstarre Epidem. im Winter (1901-5). "Klin. Jahrb., Bd. xv, p. 373 .

Netter, A. (1915): Effleacité ru sérum antiméningocoque dans 1'épidemie actuello do méningite cérébro-spinale. Bull, de l'Inst. Traubinan, 19.47.

Tranbmann, W., and Fromme, W. (1908): Beiträge für Epidemiologio 1908, p. 791 .

\section{Remarks}

ox

SOVE OI: THE EFTECTS OF EXPOSCRE TO WET COLD AND THEIR PREVENTION. (PREVENTION OF "TROST-BITE," "TRENCI. FOOT," "WATER-BITE.")

BY

S. DELÉPINE, M.B.EdiN., M.Sc.M.X.H. JIRLCTOH OF THE PCLLIC MEALTH LABORATORY, EXIVERSTY OF MIINCHESTER.

I. Frigorism.

Is a recent communication ${ }^{1}$ I recorded some experiments showing that when the temperature of the skin is reduced by exposure to an external cold medium serious sensory disturbances; cramps, and anaesthesia are produced when the temperature of the skin is still several degrees above $\mathrm{O}^{\circ} \mathrm{C}$.

In experiments of this lind it is difficult to ascertain the cutaneous temperature absolutely because the recording instrument cannot be completely protected against the influence of the cxternal medium without cansing part of the skin to escape the same influence, but in comparative experiments it is possible to show that a reduction from $30^{\circ} \mathrm{C}$. to below $10^{\circ} \mathrm{C}$. in the indicated skin temperature is gradually and successively followed by sensations indicating irritation of the cutaneous sense organs, reflex contraction of the vessels, cramps, to which may be added after a variable time more or less complete anaesthesia and motor paralysis. These phenomena are not associated with permanent lesions when the exposure is not prolonged. They are produced in a few minutes when one of the extremities is plunged into salt water at $1^{\circ}$ or $2^{\circ}$ below $0^{\circ} \mathrm{C}$.

They occur more slowly when the temperature of the water is a few degrees above $0^{\circ} \mathrm{C}$., but when the water is unlimited in amount and circulating freely, very severe symptoms may be produced even when the temperature of the fluid is as high as $7^{\circ} \mathrm{C}$. or eren $10^{\circ} \mathrm{C}$., more especially when the individual is ill nourished, the general or local circulation is bad, and the exposed part attenuated or protected by an insufficient amount of subcutaneous fat The latter condition, which is the least important, is not negligible; as is shown by a well-linown expcriment. A block of ice being applied to the external, and a thermo meter to the internal, surface of one cheek, the thermo meter may after one hour indicate a fall of $8^{\circ} \mathrm{C}$. in a thin subject, while in a stout person the fall may be $3^{\circ} \mathrm{C}$. only.

All these phenomena occur independently of any freezing of the parts. They undoubtedly indicate that cold has a powerful action upon the peripheral nerves and end organs, the vasomotor mechanism, the voluntary muscles, etc. These effects are, however, quite different from the more permanent Lesions caused by freezing, and occurring in the blood, blood and lymph vessels, nerves, muscles, etc., which have been described by Pouchet, 'Tillaux and Grancher, Jamain and Terrier, Cohnheim, and others, in connexion with frost-bite.

Repeated or prolonged cooling of the skin to a tem. perature a few degrees only above 0 C. is, however, also iable to produce permanent effects, and in the course my investigations I have observed in a foot which had been cooled several times evidences of permanent increase of irritability of some cutaneous nerves, probably indicating some slight localized peripheral neuritis, and a tendency to disturbances of circulation predisposing to excessive liability to coldness of the extremity.

These effects are not properly covered by the names "frost-bite," "trench-foot," "water-bite," but correspond to a state which 'is better defined by the term "froidure," used by some French writers, or its English equivalent " frigorism," suggested by me.

This state is produced when the cooling of the boaly or any part of it is progressive--that is, when it cannot be compensated by the production in the tissues, and the distribution by the circulating blood, of a sufficient amount of heat. Frigorism may be general or local.

When the cooling of a part reaches a certain point, the functions of the tissues are interfered with to un extent determined by the nature of the tissue, the temperature and the duration of the exposure. When the freezing. point is reached certain mechanical complications connected with the change of state are superadded to the effects of lowering of temperature.

When a body is surrounded by a medium at a lower temperature than itself, heat passes from the body into the medium until the temperature of both is the same.

The rapidity of this exchange is determined by many woll-known factors. The loss of heat from any part of the body of an animal is governed mostly by the following conditions :

1. The temperature, the thermo-conductivity, tho volume, and the movements of the external medium.

2. The duration of the exposure.

3. The bulk, movements, and superficial area of the part exposed.

4. The thermo-conductivity of the tissues and moro particularly of the integuments.

5. The amount and velocity of the flow of blood through the part.

6. The state of nutrition, activity and soundness of the tissues locally and generally (the kind and amount of food available being included under nutrition).

The importance of all these factors is a matter of general experience and is capable of experimental proof. Some experiments bearing upon this aspect of the question have been related in my previous communication.

With regard to the share taken by the nature of the externial media, it is sufficient to refer to some well. known facts. Exposure to dry air at $0^{\circ}$ C. does not materially affect a.healthy, active, well-clothed person. Arctic explorers have been able to bear very much lower temperatures without serious consequences on account of the dryness of the air in the polar regions. Exposure to damp air at $0^{\circ} \mathrm{C}$. or several degrees higher produces a very marked sensation of cold which is distinctly uncomfortable.

Immersion in water at $0^{\circ} \mathrm{C}$ is immediately followed by a sensation of intense cold, and within a few minutes loss of sensation and paralysis occru.

Complete contact of the skin with bars of metal at $0^{\circ}$ is immediately painful, and if the temperature of the metal is a few degrees below $0^{\circ}$, the tissues in contact with it are rapidly frozen.

With the object of determining to what extent the low 